\title{
A major change in North Atlantic deep water circulation 1.6 million years ago
}

\author{
N. Khélifi ${ }^{1, *}$ and M. Frank ${ }^{1}$ \\ ${ }^{1}$ GEOMAR Helmholtz Centre for Ocean Research Kiel, Wischhofstraße 1-3, 24148 Kiel, Germany \\ *present address: Springer, Earth Sciences and Geography Editorial, Tiergartenstraße 17, 69121 Heidelberg, Germany \\ Correspondence to: N. Khélifi (nabil.khelifi@ springer.com)
}

Received: 11 November 2013 - Published in Clim. Past Discuss.: 3 December 2013

Revised: 10 June 2014 - Accepted: 10 June 2014 - Published: 29 July 2014

\begin{abstract}
The global ocean-climate system has been highly sensitive to the formation and advection of deep overflow water from the Nordic Seas as integral part of the Atlantic Meridional Overturning Circulation (AMOC) but its evolution over the Pliocene-Pleistocene global cooling is not fully understood. In particular, changes in the sources and mixing of prevailing deep waters that were involved in driving overturning throughout the Pliocene-Pleistocene climate transitions are not well constrained. Here we investigate the evolution of a substantial deep southward return overflow of the AMOC over the last 4 million years. We present new records of the bottom-water radiogenic neodymium isotope $\left(\varepsilon_{\mathrm{Nd}}\right)$ variability obtained from three sediment cores (DSDP site 610 and ODP sites 980/981 and 900) at water depths between 2170 and $5050 \mathrm{~m}$ in the northeast Atlantic. We find that prior to the onset of major Northern Hemisphere glaciation $(\mathrm{NHG}) \sim 3$ million years ago $(\mathrm{Ma}), \varepsilon_{\mathrm{Nd}}$ values primarily oscillated between -9 and -11 at all sites, consistent with enhanced vertical mixing and weak stratification of the water masses during the warmer-than-today Pliocene period. From $2.7 \mathrm{Ma}$ to $\sim 2.0 \mathrm{Ma}$, the $\varepsilon_{\mathrm{Nd}}$ signatures of the water masses gradually became more distinct, which documents a significant advection of Nordic Seas overflow deep water coincident with the intensification of NHG. Most markedly, however, at $\sim 1.6 \mathrm{Ma}$ the interglacial $\varepsilon_{\mathrm{Nd}}$ signatures at sites 610 (2420 m water depth (w.d.)) and 980/981 (2170 m w.d.) synchronously and permanently shifted by 2 to $3 \varepsilon_{\mathrm{Nd}}$ units to less radiogenic values, respectively. Since then the difference between glacial and interglacial $\varepsilon_{\mathrm{Nd}}$ values has been similar to the Late Quaternary at each site. A decrease of $\sim 2 \varepsilon_{\mathrm{Nd}}$ units at $1.6 \mathrm{Ma}$ was also recorded for the deepest water masses by site 900 ( $\sim 5050$ m w.d.), which thereafter, however, evolved
\end{abstract}

to more radiogenic values again until the present. This major $\varepsilon_{\mathrm{Nd}}$ change across the $1.6 \mathrm{Ma}$ transition reflects a significant reorganization of the overturning circulation in the northeast Atlantic paving the way for the more stratified water column with distinct water masses prevailing thereafter.

\section{Introduction}

The reconstruction of past changes in ocean circulation enables the assessment of the role of the ocean in the development of the global climate system. In particular, changes in the cold, dense overflow from the Greenland-IcelandNorwegian (GIN) seas into the deep North Atlantic and the compensating northward flow of warm, saline surface waters, as part of the Gulf Stream-North Atlantic Current (NAC) system forming the Atlantic Meridional Overturning Circulation (AMOC) and the global thermohaline circulation, have had a significant impact on regional and global climate. It is therefore crucial to constrain past changes of this conveyor belt system and to evaluate its role in North Atlantic and global circulation and climate, especially over the Pliocene-Pleistocene global cooling, during which the modern feedbacks and mechanisms driving the global climate system developed. In fact, the long-term climatic cooling during the Pliocene-Pleistocene climate transitions and increased glacial-interglacial cyclicity are suggestive of important changes in the global climate system (e.g., Lisiecki and Raymo, 2007). It has been reported that changes in ocean circulation, in particular in the northern North Atlantic near the sites of deep-water formation, have played an important role in these global climate changes (e.g., Raymo et al., 1998; 


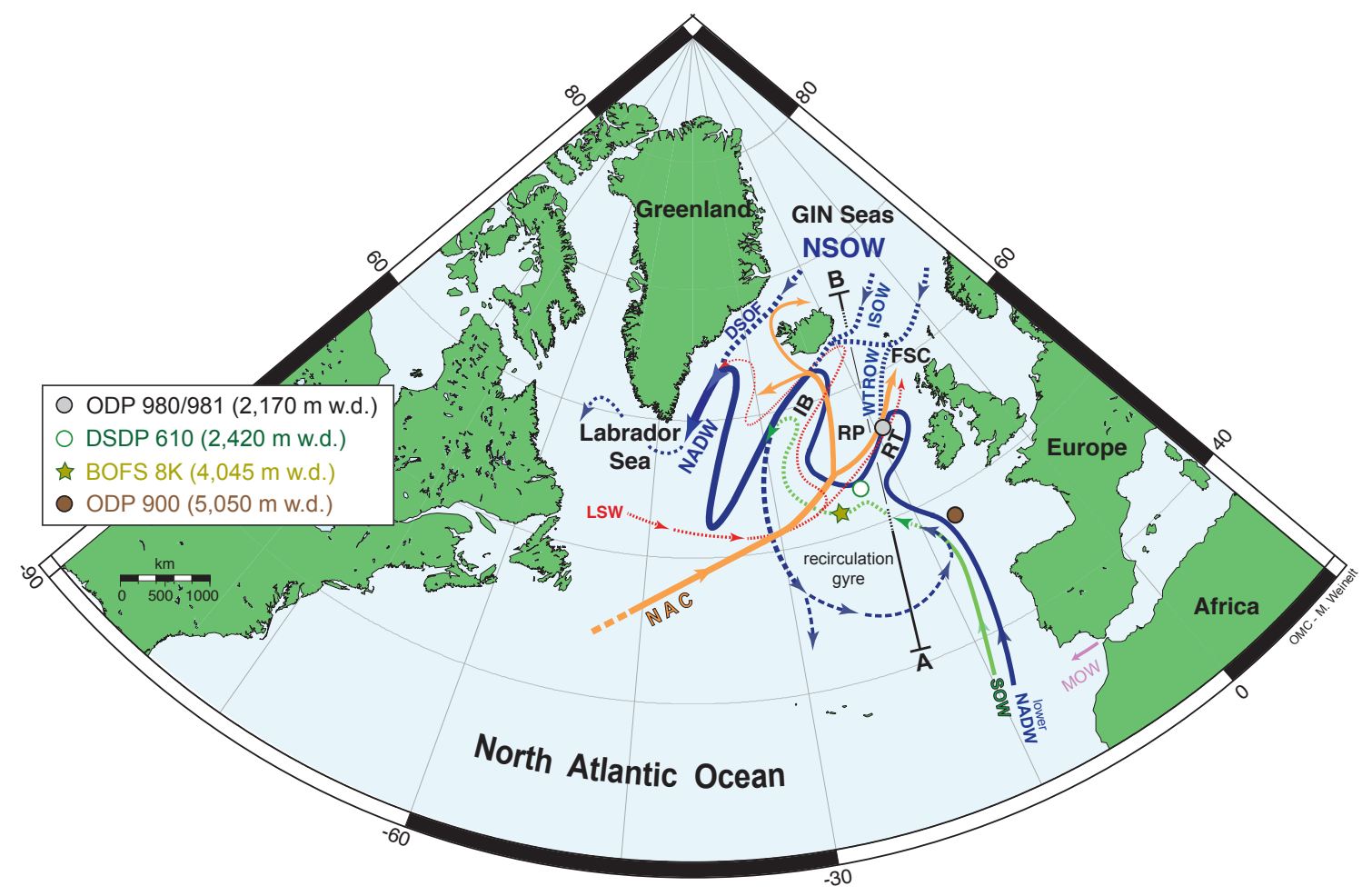

Figure 1. Circulation pattern in the modern North Atlantic with locations of study sites and core BOFS 8K (adopted from Manighetti and McCave, 1995). Nordic Seas overflow water (NSOW) consists of Iceland-Scotland, Denmark Strait, and Wyville Thomson Ridge overflow water (ISOW, DSOW, and WTROW, respectively). Southern Ocean water (SOW) and overlying lower (old) NADW mix with NSOW south of Iceland Basin (IB). A branch of this water mass flows back to form a cyclonic recirculation gyre south of the Rockall Plateau (RP). Dashed arrows indicate overflow pathways: NAC - North Atlantic Current, GIN - Greenland-Iceland-Norwegian, NADW - North Atlantic deep water, LSW - Labrador Sea Water, and MOW - Mediterranean outflow water. Cross-section (A-B) shows water mass distribution in the modern northeast Atlantic (see Fig. 2).

Ravelo et al., 2004; Hodell and Venz-Curtis, 2006; Sarnthein et al., 2009; Etourneau et al., 2010; Lawrence et al., 2010, 2013; Lisiecki, 2014).

It is the aim of this study to reconstruct the distribution and mixing of water masses in the northern northeast Atlantic in an attempt to reconstruct the evolution of the deep return overflow limb of the AMOC during the Pliocene-Pleistocene climate transitions. In particular, we aim to investigate when and how the transition to the more pronounced $100 \mathrm{kyr}$ Late Quaternary style cyclicity of glacial-interglacial climates and closely linked deep ocean circulation occurred, which still prevails today. To reach this goal, we focus on a region near the deep-water convection sites of the GIN seas due its sensitivity and capability of propagating climate signals regionally and around the globe throughout the ocean and atmosphere system (e.g., Imbrie et al., 1993; Ganopolski and Rahmstorf, 2001).

We trace changes of deep-water formation and of the distribution and mixing of water masses in the deep northeast Atlantic using the radiogenic neodymium $(\mathrm{Nd})$ isotope composition of past bottom waters extracted from the authigenic ferromanganese (Fe-Mn) coatings of deep sea sediment par- ticles and of foraminiferal shells at three DSDP/ODP core sites near the GIN seas overflow over the last 4 million years. In their source areas, water masses are imprinted with the $\mathrm{Nd}$ isotope signature of the rocks of the adjacent landmasses through weathering processes. The $\mathrm{Nd}$ isotope signatures are expressed as $\varepsilon_{\mathrm{Nd}}$ values corresponding to the deviation of the measured ${ }^{143} \mathrm{Nd} /{ }^{144} \mathrm{Nd}$ ratio of a sample from that of the chondritic uniform reservoir $($ CHUR $=0.512638)$, multiplied by 10000 (Jacobsen and Wasserburg, 1980). Old continental rocks contribute much lower $\varepsilon_{\mathrm{Nd}}$ values than younger mantle-derived material (e.g., Goldstein and O'Nions, 1981). Given that $\mathrm{Nd}$ has an average global oceanic residence time of $\sim 400-700 \mathrm{yr}$ (Rempfer et al., 2011) and differences in $\varepsilon_{\mathrm{Nd}}$ between water masses are large enough to be detectable (cf. Frank, 2002), Nd isotopes have been used as a quasi conservative tracer to infer changes in past deep-water sources and their mixing within the North Atlantic basin on different timescales (e.g., O’Nions et al., 1998; Burton et al., 1999; Roberts et al., 2010; Crocket et al., 2011; Piotrowski et al., 2012). 
(A)

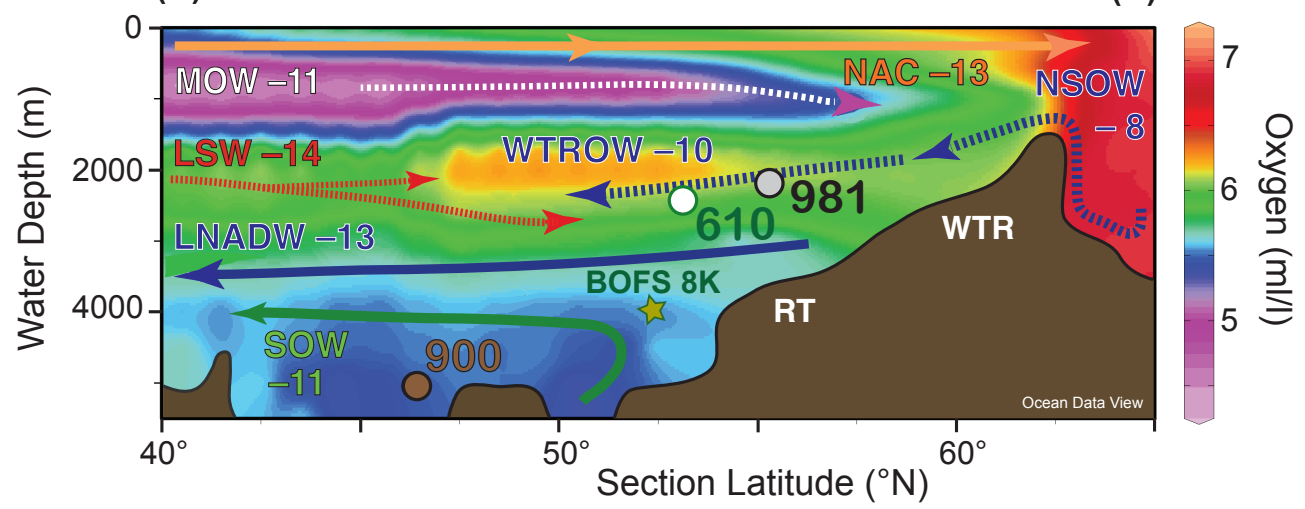

Figure 2. Modern water mass distribution based on oxygenation $\left(\mathrm{mL} \mathrm{L}^{-1}\right.$; data from world ocean database using ocean data view software; Schlitzer, 2013) and associated $\varepsilon_{\mathrm{Nd}}$ signature in the northeast Atlantic from actual water column measurements (Lacan and Jeandel, 2004a, b, 2005; Rickli et al., 2009), near-core top leachates, and foraminifera (Crocket et al., 2011; Piotrowski et al., 2013; this study). WTR Wyville Thomson Ridge, RT - Rockall Trough, NAC - North Atlantic Current, NSOW - Nordic Seas overflow water, LSW - Labrador Sea Water, MOW - Mediterranean outflow water, WTROW - Wyville Thomson Ridge overflow water, NADW - North Atlantic deep water, and SOW - Southern Ocean water.

\subsection{Study area}

Modern circulation patterns in the North Atlantic result in an $\varepsilon_{\mathrm{Nd}}$ value near -13 for the northward flow of the NAC, whereas $\varepsilon_{\mathrm{Nd}}$ values of -9 or above characterize the deep southward return overflow from the GIN seas that contributes to the formation of lower North Atlantic deep water (NADW; Lacan and Jeandel, 2004a, b, 2005). The easternmost part of the GIN seas overflow occurs through the Faroe-Shetland Channel across the Wyville Thomson Ridge into the Rockall Trough with a typical $\varepsilon_{\mathrm{Nd}}$ signature of -10.3 (Crocket et al., 2011) as a consequence of the entrainment of the overlying NAC (Sherwin et al., 2008; Figs. 1 and 2).

Sediments obtained from two core sites close to the GIN seas overflow serve to reconstruct its variability through time (Figs. 1 and 2). The Ocean Drilling Program (ODP) site $980 / 981\left(55^{\circ} 29^{\prime} \mathrm{N}, 14^{\circ} 42^{\prime} \mathrm{W} ; 2170 \mathrm{~m}\right.$ water depth (w.d.)) is located at the southernmost edge of the tongue of Wyville Thomson Ridge overflow water (WTROW; Johnson et al., 2010). This location is therefore ideally suited to sensitively monitor past changes in the flow of WTROW into Rockall Trough. The Deep Sea Drilling Project (DSDP) site 610 $\left(53^{\circ} 13^{\prime} \mathrm{N}, 18^{\circ} 53^{\prime} \mathrm{W} ; 2420 \mathrm{~m}\right.$ w.d.) is also located nearby, but at the lower boundary of the WTROW tongue. Underneath deep-water masses prevail that consist of Labrador Sea Water (LSW) and (older) lower NADW, which is mixed with relatively cold and less saline Southern Ocean water (SOW), a transformed derivative of Antarctic Bottom Water (AABW; e.g., Tarakanov et al., 2013; Fig. 2). This lower NADW fills most of the northeast Atlantic below $2500 \mathrm{~m}$ today (McCartney, 1992). We thus also included deep ODP site 900 $\left(46^{\circ} 40^{\prime} \mathrm{N}, 11^{\circ} 36^{\prime} \mathrm{W} ; 5050 \mathrm{~m}\right.$ w.d.) to reconstruct potential changes in the abyssal circulation of the lower NADW and SOW. With $\varepsilon_{\mathrm{Nd}}$ values of SOW around -8.5 at its source
(Jeandel, 1993; Stichel et al., 2012), site 900 should be sensitive to changes in the relative influence of northern versus southern source waters, as has been demonstrated for other sites further south on glacial-interglacial timescales of the latest Quaternary (e.g., Roberts et al., 2010).

\section{Methods}

The bottom-water Nd isotope composition was extracted from the ferromanganese coatings of $\sim 2 \mathrm{~g}$ of dried bulk sediment by leaching following the analytical protocol of Gutjahr et al. (2007). The Nd in the leach solutions was chemically treated and purified following the protocol of Cohen et al. (1988). Nd isotope compositions were measured on a $\mathrm{Nu}$ Instruments multi collector inductively coupled plasma mass spectrometer at GEOMAR Kiel. All Nd isotope ratios presented were normalized to the accepted value for the standard JNdi-1 of 0.512115 (Tanaka et al., 2000). External reproducibility was assessed by repeated measurements of the JNdi-standard yielding $2 \sigma$ uncertainties of \pm 0.2 to $\pm 0.4 \varepsilon_{\mathrm{Nd}}$ units during the different measurement sessions.

In order to overcome potential problems of contamination with highly radiogenic $\mathrm{Nd}$ leached from basaltic glasses or ash at site 610, we also used Fe-Mn oxide coatings on shells of mixed species of planktonic foraminifera to extract the $\varepsilon_{\mathrm{Nd}}$ signature of bottom waters following the cleaning procedure of Roberts et al. (2010). Between 30 and $80 \mathrm{mg}$ of the shells were picked from the $>250 \mu \mathrm{m}$ fraction. Samples were split into one-third of the samples for analysis as "unclean" foraminifera (not reductively cleaned) and the remaining two-thirds of the sample underwent oxidative-reductive cleaning. The $\varepsilon_{\mathrm{Nd}}$ signatures of cleaned and "uncleaned" foraminifera were always indistinguishable within analytical 


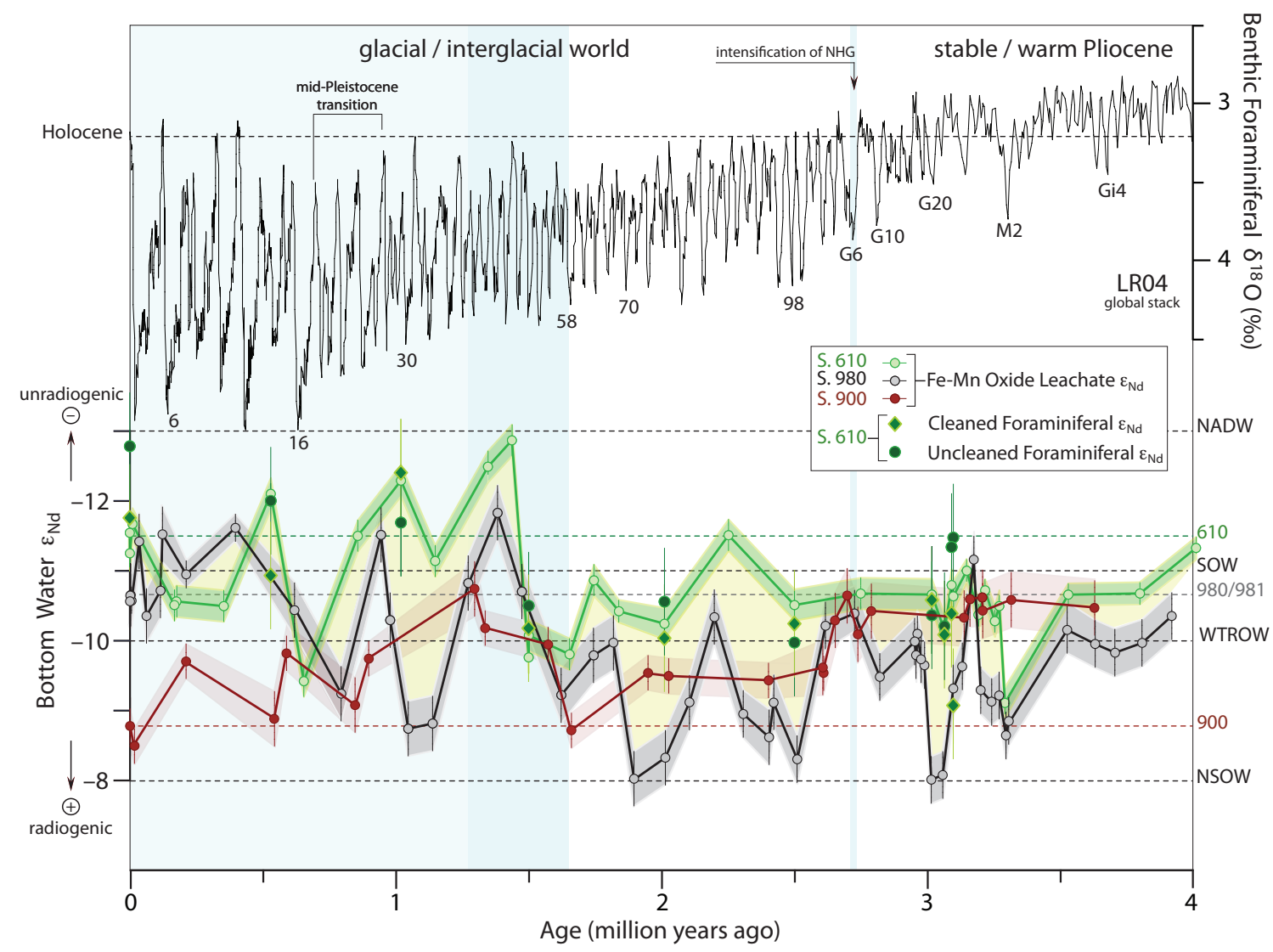

Figure 3. Changes in deep-water sources and water mass mixing in the northeast Atlantic during the past 4 million years as reflected by bottom-water $\varepsilon_{\mathrm{Nd}}$ signatures at site 980/981 (black; $2170 \mathrm{~m}$ water depth), site 610 (green; $2420 \mathrm{~m}$ w.d.), and site 900 (brown; $5050 \mathrm{~m}$ w.d.). Error bars and colored areas mark the $2 \sigma$ uncertainties of the measurements. The offset between $\varepsilon_{\mathrm{Nd}}$ records at sites $980 / 981$ and 610 is displayed in yellow. Horizontal dashed lines mark inferred modern bottom-water $\varepsilon_{\mathrm{Nd}}$ signature at study sites and the northeast Atlantic from proximally water column measurements (Lacan and Jeandel, 2004a, b, 2005; Rickli et al., 2009) and near-core top leachates and foraminifera (Crocket et al., 2011; Piotrowski et al., 2013; this study). The numbers on the global benthic foraminiferal $\delta^{18}$ O stack LR04 of Lisiecki and Raymo (2005) correspond to glacial marine isotope stages (MIS). NADW - North Atlantic deep water, SOW - Southern Ocean water, WTROW - Wyville Thomson Ridge overflow water, and NSOW - Nordic Seas overflow water.

uncertainty although external reproducibility was $\pm 0.9 \varepsilon_{\mathrm{Nd}}$ units for these data due to smaller amounts of $\mathrm{Nd}$ present in the samples (Fig. 3). Moreover, $\varepsilon_{\mathrm{Nd}}$ data of both mixed planktonic foraminifera and bulk sediment leaches were generally indistinguishable and showed the same trends of the downcore records. We thus did not generate an additional foraminiferal $\varepsilon_{\mathrm{Nd}}$ record for nearby site $980 / 981$. At site 900 , planktonic foraminifera are not sufficiently abundant to generate an $\varepsilon_{\mathrm{Nd}}$ record, which is why we base our reconstructions only on the bulk sediment leaches. The results demonstrate that the authigenic ferromanganese coatings of both mixed planktonic foraminifera and of bulk sediment preserved a reliable bottom-water $\varepsilon_{\mathrm{Nd}}$ signature at the investigated sites in the North Atlantic.

The age model for site 610 has been adopted from De Schepper and Head (2008) and for site 980/981 from Lisiecki and Raymo (2005). The age model for site 900 integrates evidence from shipboard biostratigraphy and magnetostratig- raphy of ODP Leg 173 (Zhao et al., 2001). In order to better constrain the ages for selected samples at site 900, we sampled only within the intervals of biostratigraphic and magnetostratigraphic age control points.

All data presented in this study are available in the Supplement (Table S1).

\section{Results and discussion}

Modern and Holocene bottom-water $\varepsilon_{\mathrm{Nd}}$ signatures of four samples of shallower site 980/981 extracted from ferromanganese coatings of bulk sediments yield an average value of $-10.6 \pm 0.2$, similar to estimated values for WTROW at the same site for the late Holocene (Crocket et al., 2011; Fig. 3). The late Holocene $\varepsilon_{\mathrm{Nd}}$ signature at site 610, which was also extracted from Fe-Mn coatings of bulk sediments is $-11.5 \pm 0.2$. This value is within error identical to the 
bottom-water signature extracted from Fe-Mn coatings precipitated on mixed (cleaned) planktonic foraminifera of the same sample (Fig. 3; Table S1). These values are also within the $\varepsilon_{\mathrm{Nd}}$ range of modern bottom water at nearby locations (Lacan and Jeandel, 2004a, b, 2005; Rickli et al., 2009).

For site 900 , the $\varepsilon_{\mathrm{Nd}}$ signature of the youngest sediments is $-9 \pm 0.2$ which is $\sim 2 \varepsilon_{\mathrm{Nd}}$ units more positive than the water column signature of a $\sim 400 \mathrm{~m}$ shallower water mass nearby in the Bay of Biscay (Rickli et al., 2009) and is also slightly more positive than the modern $\varepsilon_{\mathrm{Nd}}$ signature of AABW-derived deep water further south near Cape Verde $\left(\varepsilon_{\mathrm{Nd}}=-9.6\right.$; Godfrey et al., 2009). This would indicate that water masses with similar or more positive $\varepsilon_{\mathrm{Nd}}$ signatures were admixed to the bottom waters of deep site 900 , which most likely overflowed from the GIN seas as part of the Iceland-Scotland overflow water (ISOW; modern $\varepsilon_{\mathrm{Nd}}=$ -8 ; Lacan and Jeandel, 2005) and were then advected across the Iceland-Scotland gap into the recirculation gyre south of the Iceland Basin (McCartney, 1992; Figs. 1 and 2). However, a similarly radiogenic $\varepsilon_{\mathrm{Nd}}$ signature of -8 was also recorded for the last glacial at nearby core site BOFS $8 \mathrm{~K}$ south of Rockall Plateau at $4045 \mathrm{~m}$ water depth located under the same influence of the recirculation gyre (Piotrowski et al., 2012), most likely as a response to intermittent contributions from GIN seas overflow. This suggests that the more radiogenic $\varepsilon_{\mathrm{Nd}}$ signature extracted from the bulk surface sediment Fe-Mn coatings at site 900 rather represents a glacial signature most likely due to loss of the Holocene sediment section during drilling and we thus consider the extracted bottomwater signatures reliable.

The downcore $\varepsilon_{\mathrm{Nd}}$ records of sites 980/981 and 610 show broadly similar oscillations $\sim 1 \varepsilon_{\mathrm{Nd}}$ unit higher than today around average levels of $-9.5 \pm 0.4$ and $-10.5 \pm 0.3$, respectively, over most of the 4-million-year-long interval investigated except for the last 500000 years (Fig. 3). The general similarity of the two $\varepsilon_{\mathrm{Nd}}$ records suggests a largely persistent advection of the same northern source deep waters. On average, an offset of $\sim 1 \varepsilon_{\mathrm{Nd}}$ unit (displayed in yellow in Fig. 3) between the two records reflects the presence of a water mass with slightly lower $\varepsilon_{\mathrm{Nd}}$ signature at $\sim 250 \mathrm{~m}$ deeper site 610 . This is most likely a result of persistent mixing with less radiogenic underlying LSW and/or lower NADW (present-day $\varepsilon_{\mathrm{Nd}}=-14$ and -13 , respectively; Lacan and Jeandel, 2005).

However, unlike site 610, the record of site 980/981, which is more proximal to the GIN seas overflow (Fig. 2), is intersected by distinct positive excursions of $\sim 2 \varepsilon_{\mathrm{Nd}}$ units reaching the modern level of the Nordic Seas overflow at -8 to -9 (Lacan and Jeandel, 2004a, b, 2005; Figs. 3, 4 and 5), in particular during glacial marine isotope stages (MIS) G20 (3.02 Ma), 94 (2.4 Ma) and 76 (2.0 Ma), but also during interglacial MIS 99 (2.5 Ma) and 71 (1.89 Ma). Only during the cold Mammoth subchron (MIS M2) near 3.3 Ma both records similarly display a major positive excursion reaching -9 . Apparently, both sites were under the influence of similar water masses with positive $\varepsilon_{\mathrm{Nd}}$ signature during that time

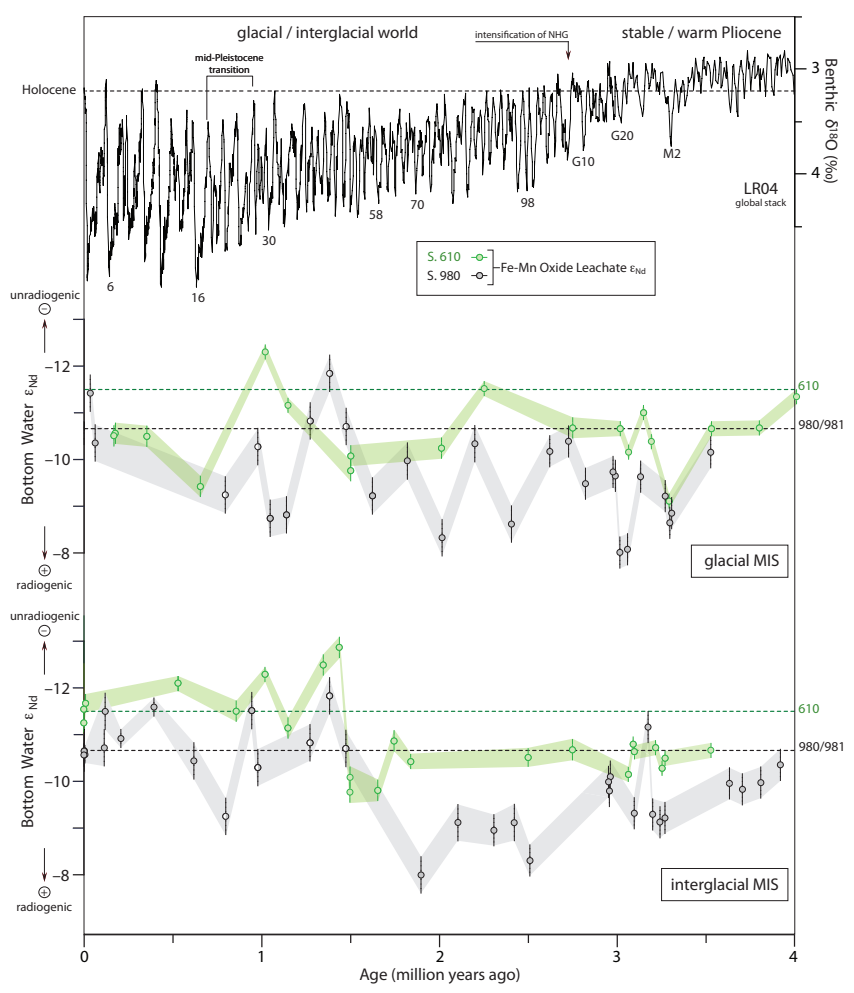

Figure 4. Comparison between changes in bottom-water $\varepsilon_{\mathrm{Nd}}$ signatures at site 980/981 (grey dots; $2170 \mathrm{~m}$ water depth) and site 610 (green dots; $2420 \mathrm{~m}$ w.d.) during the studied glacial and interglacial marine isotope stages (MIS) as reflected in the global benthic foraminiferal $\delta^{18} \mathrm{O}$ stack LR04 of Lisiecki and Raymo (2005) for the last 4 million years. At site 980/981 samples reflecting the transition from glacial to interglacial condition are shown in dots colored half grey. Error bars and colored areas mark the $2 \sigma$ uncertainties of the measurements. Horizontal dashed lines mark suggested modern bottom-water $\varepsilon_{\mathrm{Nd}}$ signature at study sites.

of major glacioeustatic sea level drop (De Schepper et al., 2013 and references therein). This indicates that WTROW most likely overflowed at a deeper level than today reaching at least site 610 during MIS M2. Apart from this short-lived glaciation and the relatively cold MIS G20, the warmer-thantoday mid- to late Pliocene was marked on average by $\varepsilon_{\mathrm{Nd}}$ values near -10 at all sites, which differs markedly from the clearly distinct modern $\varepsilon_{\mathrm{Nd}}$ signatures at each site. This indicates somewhat less stratified water masses and potentially a slightly weaker overturning circulation than today in the North Atlantic, but certainly not stronger as inferred by other marine proxy records (summarized in Zhang et al., 2013) given that the distinct signatures of the newly subducted water masses are not observed.

Only after about $2.7 \mathrm{Ma}$ (glacial MIS G6/G4) until $2.0 / 1.8 \mathrm{Ma}$, the offset between the two $\varepsilon_{\mathrm{Nd}}$ records at sites 980/981 and 610 significantly increased to reach on average 1.5 to $2 \varepsilon_{\mathrm{Nd}}$ units difference during a time interval when the stacked benthic $\delta^{18} \mathrm{O}$ (ice volume) LR04 record started 


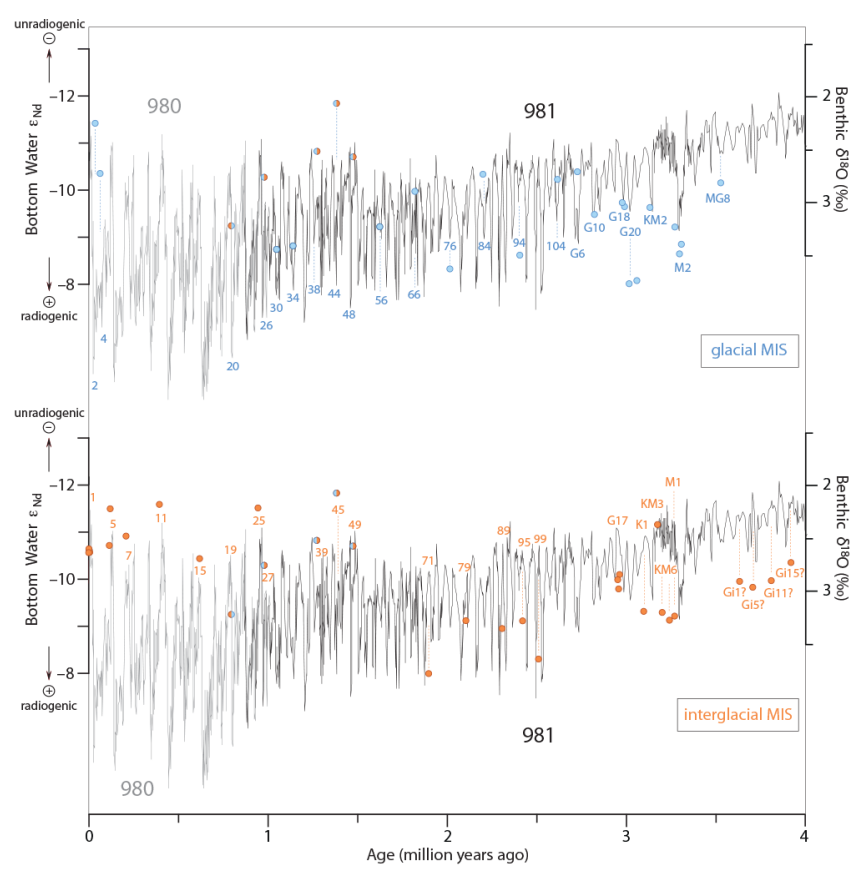

Figure 5. Comparison between changes in bottom-water $\varepsilon_{\mathrm{Nd}}$ signatures and benthic foraminiferal $\delta^{18} \mathrm{O}$ values at site $980 / 981$ for glacial (blue dots) and interglacial (red dots) marine isotope stages (MIS) during the last 4 million years (benthic $\delta^{18} \mathrm{O}$ data from Raymo et al., 2004; Lisiecki and Raymo, 2005 and references therein). Samples reflecting the transition from glacial to interglacial condition are shown in dots colored in blue and red.

to oscillate for the first time above the present interglacial level (Lisiecki and Raymo, 2005; Fig. 3). This significant offset in $\varepsilon_{\mathrm{Nd}}$ signatures was mainly a consequence of the shift towards more radiogenic $\varepsilon_{\mathrm{Nd}}$ values at site 980/981. This shift points to enhanced advection of more radiogenic deep overflow from the Nordic Seas after 2.7 Ma, closely associated with the onset of major NHG. This close association is in agreement with previous findings on strengthened deep-water convection in the Nordic Seas accompanying the intensification of NHG (Sarnthein et al., 2009). Accordingly, the $\varepsilon_{\mathrm{Nd}}$ difference after $2.7 \mathrm{Ma}$ documents an enhanced North Atlantic deep overturning. These results complement the available deep ocean $\delta^{13} \mathrm{C}$ data which did not clearly show a major change of NADW ventilation with the intensification of NHG (e.g., Raymo et al., 1992; Haug and Tiedemann, 1998). We propose that the increase in the formation of newly ventilated and nutrient-depleted deep waters of the Nordic Seas may have helped to maintain an enhanced ventilation of the Atlantic Ocean and in turn a strong biological pump in the global ocean (e.g., Sigman et al., 2010). This was crucial notably during a time of major reduction in Antarctic-sourced ventilation of the deep ocean over the $\sim 2.7$ Ma transition (Hodell and Venz-Curtis, 2006). The enhanced global ocean biological pump may have increased the quantity of carbon dioxide $\left(\mathrm{CO}_{2}\right)$ sequestered in the abyssal

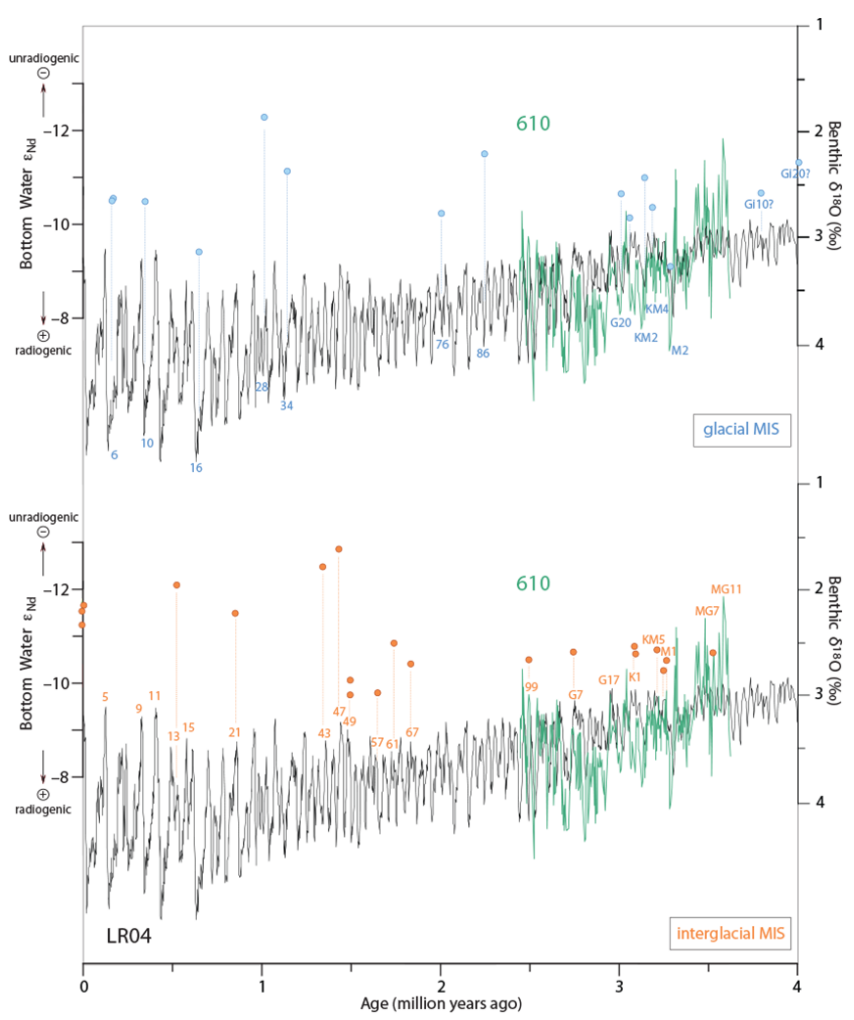

Figure 6. Comparison between changes in bottom-water $\varepsilon_{\mathrm{Nd}}$ signatures and benthic foraminiferal $\delta^{18} \mathrm{O}$ values at site 610 and the global benthic foraminiferal $\delta^{18} \mathrm{O}$ stack LR04 of Lisiecki and Raymo (2005) for glacial (blue dots) and interglacial (red dots) marine isotope stages (MIS) during the last 4 million years (benthic $\delta^{18} \mathrm{O}$ data at site 610 are from Kleiven et al., 2002 using the age model of De Schepper et al., 2008).

basins and thus overprinted the apparently absent ventilation signature in the Atlantic $\delta^{13} \mathrm{C}$ data. This is fully consistent with the relatively rapid decline in atmospheric $\mathrm{CO}_{2}$ that was observed during the severe deterioration of global climate over the intensification of the NHG (Seki et al., 2010).

Most markedly, after interglacial MIS 71/59 (1.89-1.68 Ma) a pronounced shift of 2 to $3 \varepsilon_{\mathrm{Nd}}$ units towards less radiogenic values occurred resulting in values of -11.5 at site 980/981 and -13 at site 610 near glacial-interglacial MIS $45 / 44(\sim 1.4 \mathrm{Ma})$. This major $\varepsilon_{\mathrm{Nd}}$ shift primarily occurred during interglacial intervals at both sites and if compared to the Pliocene levels was less pronounced at site 980/981 than at site 610. Moreover, after MIS 49/48 ( 1.5 Ma) pronounced oscillations of up to $\sim 3 \varepsilon_{\mathrm{Nd}}$ units between glacial and interglacial climate states at both sites occurred (Figs. 36), which are similar to the Last Glacial Maximum-Holocene range for nearby deeper core BOFS $8 \mathrm{~K}\left(\sim 4 \varepsilon_{\mathrm{Nd}}\right.$ units; Piotrowski et al., 2012). This prominent shift is corroborated by $\varepsilon_{\mathrm{Nd}}$ measurements of cleaned and "uncleaned" planktonic foraminifera at site 610 , further supporting the reliability of our bottom-water $\varepsilon_{\mathrm{Nd}}$ reconstruction from bulk sediment 
leachates (Figs. 3 and 4). At the deepest site 900, the $\varepsilon_{\mathrm{Nd}}$ values display a similar but stepwise decrease by $\sim 2 \varepsilon_{\mathrm{Nd}}$ units from 1.65 to $1.35 \mathrm{Ma}$. However, in contrast to sites $980 / 981$ and 610 , the $\varepsilon_{\mathrm{Nd}}$ signatures at site 900 evolved to significantly more radiogenic values thereafter. In addition, site 900 has experienced less pronounced oscillations, finally reaching last glacial to modern $\varepsilon_{\mathrm{Nd}}$ levels near -9 (Fig. 3).

The concurrent shift in bottom-water Nd isotope composition at the two sites close to the GIN seas overflow at $\sim 1.68$ 1.40 Ma documents a key change in Nordic Seas overflow and climate primarily during interglacial intervals (Figs. 46). During this period of time, surface waters in the study area experienced a major cooling (summarized in Lawrence et al., 2010) that was accompanied by frequent inputs of ice rafted debris (McIntyre et al., 1999). The cooling occurred during what appeared to be a time of relatively stable polar climate and glacial ice volumes (Lisiecki and Raymo, 2005; Fig. 3). Since pertinent records (e.g., Lawrence et al., 2009; Naafs et al., 2010) do not show any coeval decrease in poleward heat and salt transport within the NAC (present day $\varepsilon_{\mathrm{Nd}}=-13$; Lacan and Jeandel, 2004a, b), which would have resulted in diminished advection of "unradiogenic" subsurface waters into the Nordic Seas, the cooling was most likely linked to an expansion of subpolar waters (present day $\varepsilon_{\mathrm{Nd}}=$ -10 to -8.5 ; Lacan and Jeandel, 2004a, b). Recent findings by Martínez-Garcia et al. (2010) show, in fact, that during that very time the sub-Arctic region underwent a substantial cooling associated with sea-ice expansion, which continued across the mid-Pleistocene transition $\sim 1.15-0.9 \mathrm{Ma}$ (McClymont et al., 2008). This major sub-Arctic cooling led to the formation and advection of cold deep waters from the GIN seas into the North Atlantic basin, which was recorded further south in the North Atlantic (ODP site 607) by a longterm decrease in NADW temperature after $\sim 1.55 \mathrm{Ma}$ (Sosdian and Rosenthal, 2009), coeval with major surface water cooling in the area (see comparison in Lawrence et al., 2010).

Assuming that the bottom-water signature at sites 610 and 980/981 originated primarily from the sinking of surface waters in the Nordic Seas similar to the modern conditions, we infer that the 1.6-1.4 Ma period reflects a major weakening of deep-water production at the Nordic Seas convection centres and consequently of Nordic Seas overflow. We propose that the major shift to less radiogenic signatures was related to a significant change in overturning circulation after 1.6 Ma rather than changes in erosional inputs and continental weathering regime. The reduced Nordic Seas overflow most likely resulted in increased admixture of LSW and lower (old) NADW in the northeast Atlantic. However, unlike other well-established paleoceanographic proxies such as stable carbon isotopes (summarized by Lisiecki, 2014), which suggest major changes in vertical, meridional and interbasinal benthic glacial $\delta^{13} \mathrm{C}$ gradients at a series of cores located in the studied region as well as other areas of the Atlantic Ocean after $\sim 1.55 \mathrm{Ma}$ (e.g., Hodell and Venz-Curtis, 2006 ), our $\varepsilon_{\mathrm{Nd}}$-based shift occurred primarily during the in- terglacials. The radiogenic $\mathrm{Nd}$ isotope composition of the glacial deep waters at our core sites has most likely been maintained by admixture of southern source waters with more radiogenic signatures.

The decrease in Atlantic overturning we observe here during interglacial stages is corroborated by studies of siliceous microfossils (e.g., Koç and Scherer, 1996; Stabell and Koç, 1996). These authors concluded based on the absence of production of silica in the surface waters of the GIN seas relative to the region south of Iceland (Koç and Flower, 1998; Koç et al., 1999) that a strong front must have existed near the Greenland-Scotland Ridge during most of the interglacials of the early to mid-Pleistocene (summarized by Raymo et al., 2004). This was reflected by the presence of a pronounced low- $\delta^{13} \mathrm{C}$ water mass at mid-depth throughout the $41 \mathrm{kyr}$ world $\sim 1.8-1.2 \mathrm{Ma}$. Accordingly, the negative $\varepsilon_{\mathrm{Nd}}$ shift we observe after 1.8/1.6 Ma supports that the $\delta^{13} \mathrm{C}$ signals found by these authors are indeed true bottom-water geochemical signals. They considered that this $10 w-\delta{ }^{13} \mathrm{C}$ water mass observed at mid-depths in the subpolar North Atlantic (precisely at site 980/981 and more clearly at sites 983 and 984, being more influenced by the Nordic Seas overflows) may have originated in the GIN seas over that time interval. In agreement with our conclusions, these authors suggested that this could have been linked to enhanced sea ice cover in the GIN seas region which would have reduced air-sea isotopic exchange, as well as reduced exchange of surface waters with the open North Atlantic relative to the Arctic. They further suggest that under these conditions dense water formed in the GIN seas, possibly through brine rejection, continued to overflow during that time into the North Atlantic carrying the more depleted $\delta^{13} \mathrm{C}$ signatures typical of Arctic rather than North Atlantic feed waters. We rather argue based on our quasi conservative proxy that the pronounced $\varepsilon_{\mathrm{Nd}}$ shift towards less radiogenic values suggests that during that time the deep-water convection in the GIN seas and the consequent deep overflow were strongly reduced. Apparently, the dominant deep-water masses in the northern North Atlantic originated from open ocean convection in the Labrador Sea and subpolar North Atlantic during that time (modern $\varepsilon_{\mathrm{Nd}}=$ -14 to -13$)$.

In summary, the $\varepsilon_{\mathrm{Nd}}$ shift towards less radiogenic values we observe for the period of time 1.68-1.40 Ma strongly suggests a diminished production of well-ventilated deep waters from the Nordic Seas, following a major change in Atlantic overturning due to overall enhanced sea ice expansion during interglacials. Further work, including producing higher resolution $\varepsilon_{\mathrm{Nd}}$ records and particularly more reliable $p \mathrm{CO}_{2}$ estimates, are particularly needed to investigate whether these major deep Atlantic circulation changes may have altered the global ocean biological pump and thus the carbon storage after 1.6 Ma (e.g., Wang et al., 2010), at a point in time clearly preceding the main shift in amplitude and frequency of benthic $\delta^{18} \mathrm{O}$ (ice volume) record (Lisiecki and Raymo, 2005) and southward movement of the Arctic front (McClymont 
et al., 2008) during the mid-Pleistocene transition $(\sim 1.2-$ 0.8 Ma; Berger and Jansen, 1994).

The reduction in deep convection and in overflow of dense waters we propose here, however, did not translate, as possibly expected, into advection of substantial volumes of southern source water such as during the LGM and the last glacial period (e.g., Sarnthein et al., 1994; Marchitto et al., 2002). On the contrary, the $\varepsilon_{\mathrm{Nd}}$ values at deepest site 900 gradually followed the shift towards more negative values indicating the dominant presence of northern source waters in the abyssal North Atlantic. Consequently, we infer that the entire meridional overturning circulation in the northern North Atlantic decreased at least during 1.68-1.40 Ma and SOW did not reach as far North, for example, as during the last glacial period (e.g., Crocket et al., 2011; Piotrowski et al., 2012), potentially as a consequence of the smaller size of West Antarctic ice sheet and thus reduced deep-water production during that time (e.g., Naish et al., 2009).

After $\sim 1.4 \mathrm{Ma}$, a long-term trend towards more radiogenic modern-like $\varepsilon_{\mathrm{Nd}}$ signatures clearly shows that the deepest site 900 gradually experienced the enhanced admixture of southern source waters and documents the establishment of modern type deep circulation in the North Atlantic. This reorganization was accompanied by an increase in the amplitude of the $\varepsilon_{\mathrm{Nd}}$ signatures at sites 610 and $980 / 981$ on glacial-interglacial scales (Figs. 3-5). Predominantly "unradiogenic" $\varepsilon_{\mathrm{Nd}}$ signatures during interglacial intervals at these sites indicate the enhanced injection of LSW and/or (old) NADW into intermediate and deep waters in the northeast Atlantic. In contrast, the most radiogenic $\varepsilon_{\mathrm{Nd}}$ values during glacial intervals may reflect decreased entrainment of NAC and increased admixture of southern source waters with intermittent GIN seas overflow.

This major reorganization in the North Atlantic overturning circulation across the mid-Pleistocene transition is also evident from the significant increase in the glacialinterglacial amplitude of benthic $\delta^{13} \mathrm{C}$ signatures in the North Atlantic (e.g., Venz and Hodell, 2002; Hodell and VenzCurtis, 2006; Lawrence et al., 2010) indicating a change to being dominantly ventilated by NADW during interglacial periods and enhanced advection of SOW during glacial periods. Apparently, the expansion of the West Antarctic ice sheet across the mid-Pleistocene transition promoted the production and export of AABW from the Southern Ocean (e.g., Naish et al., 2009; Lawrence et al., 2010). This major change suggests that after the mid-Pleistocene transition both northern and southern hemispheric ice sheets started to exert more far-field influence on ocean circulation and climate linked to the onset of the more pronounced $100 \mathrm{kyr}$ late Quaternary style cyclicity of glacial-interglacial climates that still prevails today.

\section{Conclusions}

Based on bottom-water radiogenic neodymium isotope $\left(\varepsilon_{\mathrm{Nd}}\right)$ variability our study suggests a major reorganization of deep circulation in the northeast Atlantic after 1.6 Ma. The overflow of deep waters from the Nordic Seas significantly decreased mainly during interglacials, which had implications for the evolution of the overturning circulation in the North Atlantic. We argue that the surface water changes in the Arctic and sub-Arctic source areas (e.g., increased sea-ice expansion and enhanced surface water stratification) most likely ultimately triggered the reorganization of North Atlantic deep water circulation towards a more stratified water column and more distinct water masses after $1.4 \mathrm{Ma}$, which clearly occurred before the mid-Pleistocene transition and the onset of more pronounced late Quaternary style cycles of glacialinterglacial climates that still prevail today. This major circulation change in the deep Atlantic after $\sim 1.6 \mathrm{Ma}$ may have affected the deep ventilation rates and thus altered the ocean carbon storage. Further evidence documenting past changes in $p \mathrm{CO}_{2}$ and ice sheet dynamics is required to better understand the exact cause and implications of this important transition at $\sim 1.6-1.4 \mathrm{Ma}$.

\section{The Supplement related to this article is available online at doi:10.5194/cp-10-1441-2014-supplement.}

Acknowledgements. We thank H. Elderfield, J. Etourneau, A. Haywood, E. Martin, A. Piotrowski, M. Sarnthein, R. Schneider, R. Tiedemann, and other colleagues for helpful discussions. G. Leduc and D. Naafs commented on an early manuscript version. S. De Schepper provided data for the age models and N. Fraser helped with proofreading. C. Teschner and A. Osborne assisted with sample preparation and analyses. J. Heinze supervised the clean lab and C. Siebert maintained the mass spectrometer. S. Rieken and other students helped with careful sample preparation. Samples were provided by the Integrated Ocean Drilling Program (IODP). W. Hale and A. Wülbers helped with sampling at the IODP Bremen Core Repository. We thank D. Hodell and a second anonymous reviewer for their insightful and constructive comments, and A. Dutton for carefully handling our manuscript. C. Zeeden and S. Kaboth contributed to the discussions. N. K. acknowledges funding by the Deutsche Forschungsgemeinschaft (DFG grant KH280/1).

The service charges for this open access publication have been covered by a Research Centre of the Helmholtz Association.

Edited by: A. Dutton 


\section{References}

Berger, W. H. and Jansen, E.: Mid-Pleistocene climate shift: the Nansen connection, in: The Polar Oceans and Their Role in Shaping the Global Environment, edited by: Johannessen, O., Muench, R., and Overland, J., AGU Geophys. Monogr., 85, 295311, doi:10.1029/GM085, 1994.

Burton, K. W., Lee, D.-C., Christensen, J. N., Halliday, A. N., and Hein, J. R.: Actual timing of neodymium isotopic variations recorded by $\mathrm{Fe}-\mathrm{Mn}$ crusts in the western North Atlantic, Earth Planet. Sc. Lett., 171, 149-156, doi:10.1016/S0012821X(99)00138-7, 1999.

Cohen, A. S., O'Nions, R. K., Siegenthaler, R., and Griffin, W. L.: Chronology of the pressure-temperature history recorded by a granulite terrain, Contributions to Miner. Petrol., 98, 303-311, doi:10.1007/BF00375181, 1988.

Crocket, K. C., Vance, D., Gutjahr, M., Foster, G. L., and Richards, D. A.: Persistent Nordic deep-water overflow to the glacial North Atlantic, Geology, 39, 515-518, doi:10.1130/G31677.1, 2011.

De Schepper, S. and Head, M. J.: Age calibration of dinoflagellate cyst and acritarch events in the Pliocene-Pleistocene of the eastern North Atlantic (DSDP Hole 610A), Stratigraphy, 8, 137-161, 2008.

De Schepper, S., Groeneveld, J., Naafs, B. D. A., Van Renterghem, C., Hennissen, J., Van Renterghem, C., Hennissen, J., Head, M. J., Louwye, S., and Fabian, K.: Northern Hemisphere Glaciation during the Globally Warm Early Late Pliocene, PLoS ONE 8, e81508, doi:10.1371/journal.pone.0081508, 2013.

Etourneau, J., Schneider, R., Blanz, T., and Martinez, P.: Intensification of the Walker and Hadley atmospheric circulations during the Pliocene-Pleistocene climate transition, Earth Planet. Sci. Lett., 297, 103-110, doi:10.1016/j.eps1.2010.06.010, 2010.

Frank, M.: Radiogenic isotopes: tracers of past ocean circulation and erosional input, Rev. Geophys., 40, 1001, doi:10.1029/2000RG000094, 2002.

Ganopolski, A. and Rahmstorf, S.: Rapid changes of glacial climate simulated in a coupled climate model, Nature, 409, 153158, doi:10.1038/35051500, 2001.

Godfrey, L. V., Zimmermann, B., Lee, D.-C., King, R. L., Vervoort, J. D., Sherrell, R. M., and Halliday, A. N.: Hafnium and neodymium isotope variations in NE Atlantic seawater, Geochem. Geophy. Geosy., 10, Q08015, doi:10.1029/2009GC002508, 2009.

Goldstein, S. L. and O'Nions, R. K.: Nd and Sr isotopic relationships in pelagic clays and ferromanganese deposits, Nature, 292, 324-327, doi:10.1038/292324a0, 1981.

Gutjahr, M., Frank, M., Stirling, C. H., Klemm, V., van de Flierdt, T., and Halliday, A. N.: Reliable extraction of a deepwater trace metal isotope signal from Fe-Mn oxyhydroxide coatings of marine sediments, Chem. Geol., 242, 351-370, doi:10.1016/j.chemgeo.2007.03.021, 2007.

Haug, G. H. and Tiedemann, R.: Effect of the formation of the Isthmus of Panama on Atlantic Ocean thermohaline circulation, Nature, 393, 673-676, doi:10.1038/31447, 1998.

Hodell, D. A. and Venz-Curtis, K. A.: Late Neogene history of deepwater ventilation in the Southern Ocean, Geochem. Geophys. Geosyst., 7, Q09001, doi:10.1029/2005GC001211, 2006.

Imbrie, J., Berger, A., Boyle, E., Clemens, S., Duffy, A., Howard, W., Kukla, G., Kutzbach, J., Martinson, D., McIntyre, A., Mix,
A., Molfino, B., Morley, J., Peterson, L., Pisias, N., Prell, W., Raymo, M., Shackleton, N., and Toggweiler, J.: On the structure and origin of major glaciation cycles 2 . The 100,000-year cycle, Paleoceanography, 8, 698-735, doi:10.1029/93PA02751, 1993.

Jacobsen, S. B. and Wasserburg, G. J.: Sm-Nd isotopic evolution of chondrites, Earth Planet. Sc. Lett., 50, 139-155, doi:10.1016/0012-821X(80)90125-9, 1980.

Jeandel, C.: Concentration and isotopic composition of $\mathrm{Nd}$ in the South Atlantic Ocean, Earth Planet. Sc. Lett., 117, 581-591, doi:10.1016/0012-821X(93)90104-H, 1993.

Johnson, C., Sherwin, T., Smythe-Wright, D., Turrell, W., and Shimmield, T.: Wyville Thomson Ridge Overflow Water: spatial and temporal distribution in the Rockall Trough, Deep-Sea Res. Pt. I, 57, 1153-1162, doi:10.1016/j.dsr.2010.07.006, 2010.

Kleiven, H. F., Jansen, E., Fronval, T., and Smith, T. M: Intensification of Northern Hemisphere glaciations in the circum Atlantic region (3.5-2.4 Ma), ice-rafted detritus evidence, Palaeogeogr. Palaeoclim. Palaeoecol., 184, 213-223, doi:10.1016/S00310182(01)00407-2, 2002.

Koç, N., Hodell, D. A., Kleiven, H., and Labeyrie, L.: High-resolution Pleistocene diatom biostratigraphy of Site 983 and correlations to isotope stratigraphy, Proceedings of the Ocean Drilling Program Scientific Results, 162, 51-62, doi:10.2973/odp.proc.sr.162.035.1999, 1999.

Koç, N. and Flower, B.: High-resolution Pleistocene diatom biostratigraphy and paleoceanography of Site 919 from the Irminger Basin, Proceedings of the Ocean Drilling Program Scientific Results, 152, 209-219, doi:10.2973/odp.proc.sr.152.218.1998, 1998.

Koç, N. and Scherer, R.: Neogene diatom biostratigraphy of the Iceland Sea Site 907, Proceedings of the Ocean Drilling Program Scientific Results, 151, 61-74, doi:10.2973/odp.proc.sr.151.108.1996, 1996.

Lacan, F. and Jeandel, C.: Denmark Strait water circulation traced by heterogeneity in neodymium isotopic compositions, DeepSea Res. Pt. I, 51, 71-82, doi:10.1016/j.dsr.2003.09.006, 2004a.

Lacan, F. and Jeandel, C.: Neodymium isotopic composition and rare earth element concentrations in the deep and intermediate Nordic Seas: constraints on the Iceland Scotland Overflow Water signature, Geochem. Geophy. Geosy., 5, Q11006, doi:10.1029/2004GC000742, 2004b.

Lacan, F. and Jeandel, C.: Acquisition of the neodymium isotopic composition of the North Atlantic Deep Water, Geochemistry Geophysics Geosystems, 6, Q12008, doi:10.1029/2005GC000956, 2005.

Laskar, J., Joutel, F., and Boudin, F.: Orbital, precessional, and insolation quantities for the Earth from $-20 \mathrm{Myr}$ to $+10 \mathrm{Myr}$, Astron. Astrophys., 270, 522-533, ISSN 0004-6361, 1993.

Lawrence, K. T., Herbert, T. D., Brown, C. M., Raymo, M. E., and Haywood, A. M.: High-amplitude variations in North Atlantic sea surface temperature during the early Pliocene warm period, Paleoceanography, 24, PA2218, doi:10.1029/2008PA001669, 2009.

Lawrence, K. T., Sosdian, S., White, H. E., and Rosenthal, Y.: North Atlantic climate evolution through the Plio-Pleistocene climate transitions, Earth Planet. Sc. Lett., 300, 329-342, doi:10.1016/j.epsl.2010.10.013, 2010.

Lawrence, K. T., Sigman, D. M., Herbert, T. D., Riihimaki, C. A., Bolton, C. T., Martinez-Garcia, A., Rosell-Melé, A., and Haug, 
G. H.: Time-transgressive North Atlantic productivity changes upon Northern Hemisphere glaciation, Paleoceanography, 28, doi:10.1002/2013PA002546, 2013.

Lisiecki, L. E. and Raymo, M. E.: A Pliocene-Pleistocene stack of 57 globally distributed benthic $\delta^{18} \mathrm{O}$ records, Paleoceanography, 20, PA1003, doi:10.1029/2004PA001071, 2005.

Lisiecki, L. E. and Raymo, M. E.: Plio-Pleistocene climate evolution: trends and transition in glacial cycle dynamics, Quaternary Sci. Rev., 26, 56-69, doi:10.1016/j.quascirev.2006.09.005, 2007.

Lisiecki, L. E.: Atlantic overturning responses to obliquity and precession over the last $3 \mathrm{Myr}$, Paleoceanography, 29, doi:10.1002/2013PA002505, 2014.

Manighetti, B. and McCave, I. N.: Late Glacial and Holocene palaeocurrents around Rockall Bank, NE Atlantic Ocean, Paleoceanography, 10, 611-626, doi:10.1029/94PA03059, 1995.

Marchitto, T. M., Jr., Oppo, D. W., and Curry, W. B.: Paired benthic foraminiferal $\mathrm{Cd} / \mathrm{Ca}$ and $\mathrm{Zn} / \mathrm{Ca}$ evidence for a greatly increased presence of Southern Ocean Water in the glacial North Atlantic, Paleoceanography, 17, 1038, doi:10.1029/2000PA000598, 2002.

Martínez-Garcia, A., Rosell-Melé, A., McClymont, E. L., Gersonde, R., and Haug, G. H.: Subpolar link to the emergence of the Modern Equatorial Pacific cold tongue, Science, 328, 15501553, doi:10.1126/science.1184480, 2010.

McCartney, M. S.: Recirculating components to the deep boundary current of the Northern North Atlantic, Prog. Oceanogr., 29, 283 383, doi:10.1016/0079-6611(92)90006-1, 1992.

McClymont, E. L., Rosell-Mele, A., Haug, G., and Lloyd, J. M.: Expansion of subarctic water masses in the North Atlantic and Pacific oceans and implications for midPleistocene ice sheet growth, Paleoceanography, 23, PA4214, doi:10.1029/2008PA001622, 2008.

McIntyre, K., Ravelo, A. C., and Delaney, M. L.: North Atlantic Intermediate Waters in the Late Pliocene to Early Pleistocene, Paleoceanography, 14, 324-335, doi:10.1029/1998PA900005, 1999.

Naafs, B. D. A., Stein, R., Hefter, J., Khélifi, N., De Schepper, S., and Haug, G.: Late Pliocene changes in the North Atlantic Current, Earth Planet. Sc. Lett., 298, 434-442, doi:10.1016/j.epsl.2010.08.023, 2010.

Naish, T., Powell, R., Levy, R., Wilson, G., Scherer, R., Talarico, F., Krissek, L., Niessen, F., Pompilio, M., Wilson, T., Carter, L., DeConto, R., Huybers, P., McKay, R., Pollard, D., Ross, J., Winter, D., Barrett, P., Browne, G., Cody, R., Cowan, E., Crampton, J., Dunbar, G., Dunbar, N., Florindo, F., Gebhardt, C., Graham, I., Hannah, M., Hansaraj, D., Harwood, D., Helling, D., Henrys, S., Hinnov, L., Kuhn, G., Kyle, P., Läufer, A., Maffioli, P., Magens, D., Mandernack, K., McIntosh, W., Millan, C., Morin, R., Ohneiser, C., Paulsen, T., Persico, D., Raine, I., Reed, J., Riesselman, C., Sagnotti, L., Schmitt, D., Sjunneskog, C., Strong, P., Taviani, M., Vogel, S., Wilch, T., and Williams, T.: Obliquitypaced Pliocene West Antarctic ice sheet oscillations: Obliquitypaced Pliocene West Antarctic ice sheet oscillations, Nature, 458, 322-329, doi:10.1038/nature07867, 2009.

O’Nions, R. K., Frank, M., von Blanckenburg, F., and Ling, H.-F.: Secular variation of $\mathrm{Nd}$ and $\mathrm{Pb}$ isotopes in ferromanganese crusts from the Atlantic, Indian and Pacific Oceans, Earth Planet. Sc. Lett., 155, 15-28, doi:10.1016/S0012-821X(97)00207-0, 1998.

Piotrowski, A. M., Galy, A., Nicholl, J. A. L., Roberts, N., Wilson, D. J., Clegg, J. A., and Yu, J.: Reconstructing deglacial North and South Atlantic deep water sourcing using foraminiferal Nd isotopes, Earth Planet. Sc. Lett., 357-358, 289297, doi:10.1016/j.epsl.2012.09.036, 2012.

Ravelo, A. C., Andreasen, D. H., Lyle, M., Olivarez Lyle, A., and Wara, M. W.: Regional climate shifts caused by gradual global cooling in the Pliocene epoch, Nature, 429, 263-267, doi:10.1038/nature02567, 2004.

Raymo, M. E., Ganley, K., Carter, S., Oppo, D. W., and McManus, J.: Millennial-scale climate instability during the early Pleistocene epoch, Nature, 392, 699-702, doi:10.1038/33658, 1998.

Raymo, M. E., Hodell, D., and Jansen, E.: Response of Deep Ocean Circulation to the initiation of Northern Hemisphere Glaciation (3-2 Ma), Paleoceanography, 7, 645-672, doi:10.1029/92PA01609, 1992.

Rempfer, J., Stocker, T. F., Joos, F., Dutay, J.-C., and Siddall, M.: Modelling Nd-isotopes with a coarse resolution ocean circulation model: Sensitivities to model parameters and source/sink distributions, Geochim. Cosmochim. Acta, 75, 5927-5950, doi:10.1016/j.gca.2011.07.044, 2011.

Rickli, J., Frank, M., and Halliday, A. N.: The hafnium-neodymium isotopic composition of Atlantic seawater, Earth Planet. Sc. Lett., 280, 118-127, doi:10.1016/j.epsl.2009.01.026, 2009.

Roberts, N. L., Piotrowski, A. M., McManus, J. F., and Keigwin, L. D.: Synchronous deglacial overturning and water mass source changes, Science, 327, 75-78, doi:10.1126/science.1178068, 2010.

Sarnthein, M., Bartoli, G., Prange, M., Schmittner, A., Schneider, B., Weinelt, M., Andersen, N., and D. Garbe-Schönberg, D.: Mid-Pliocene shifts in ocean overturning circulation and the onset of Quaternary-style climates, Climates of the Past, 5, 269283, doi:10.5194/cp-5-269-2009, 2009.

Sarnthein, M., Winn, K., Jung, S., Duplessy, J.-C., Labeyrie, L., Erlenkeuser, H., and Ganssen, G.: Changes in east Atlantic deepwater circulation over the last 30,000 years: Eight time slice reconstructions, Paleoceanography, 9, 209-267, doi:10.1029/93PA03301, 1994.

Schlitzer, R.: Ocean Data View, available at: http://odv.awi.de (last access: 5 November 2011), 2013.

Seki, O., Foster, G. L., Schmidt, D. N., Mackensen, A., Kawamura, K., and Pancost, R. D.: Alkenone and boron-based Pliocene $p \mathrm{CO}_{2}$ records, Earth Planet. Sc. Lett., 292, 201-211, doi:10.1016/j.eps1.2010.01.037, 2010.

Sherwin, T. J., Griffiths, C. R., Inall, M. E., and Turrell, W. R.: Quantifying the overflow across the Wyville Thomson Ridge into the Rockall trough, Deep-Sea Res. Pt. I, 55, 396-404, doi:10.1016/j.dsr.2007.12.006, 2008.

Sigman, D. M., Hain, M. P., and Haug, G. H.: The polar ocean and glacial cycles in atmospheric $\mathrm{CO}_{2}$ concentration, Nature, 466 , 47-55, doi:10.1038/nature09149, 2010.

Sosdian, S. and Rosenthal, Y.: Deep-sea temperature and ice volume changes across the Pliocene-Pleistocene climate transitions, Science, 325, 306-309, doi:10.1126/science.1169938, 2009.

Stabell, B. and Koç, N.: Recent to mid-Miocene diatom productivity at ODP Site 907, Iceland Plateau, Proceedings of the Ocean Drilling Program Scientific Results, 151, 483-492, doi:10.2973/odp.proc.sr.151.137.1996, 1996.

Stichel, T., Frank, M., Rickli, J., and Haley, B. A.: The hafnium and neodymium isotope composition of seawater in the Atlantic sector of the Southern Ocean, Earth Planet. Sc. Lett., 317-318, 282-294, doi:10.1016/j.epsl.2011.11.025, 2012. 
Tanaka, T., Togashi, S., Kamioka, H., Amakawa, H., Kagami, H., Hamamoto, T., Yuhara, M., Orihashi, Y., Yoneda, S., Shimizu, H., Kunimaru, T., Takahashi, K., Yanagi, T., Nakano, T., Fujimaki, H., Shinjo, R., Asahara, Y., Tanimizu, M., and Dragusanu, C.: JNdi-1: a neodymium isotopic reference in consistency with LaJolla neodymium, Chem. Geol., 168, 279-281, doi:10.1016/S0009-2541(00)00198-4, 2000.

Venz, K. A. and Hodell, D. A.: New evidence for changes in Plio-Pleistocene deep water circulation from Southern Ocean ODP Leg 177 Site 1090, Palaeogeogr. Palaeocl., 182, 197-220, doi:10.1016/S0031-0182(01)00496-5, 2002.

Wang, P., Tian, J., and Lourens, L. J.: Obscuring of long eccentricity cyclicity in Pleistocene oceanic carbon isotope records, Earth Planet. Sc. Lett., 290, 319-30, doi:10.1016/j.eps1.2009.12.028, 2010.
Zhang, Z.-S., Nisancioglu, K. H., Chandler, M. A., Haywood, A. M., Otto-Bliesner, B. L., Ramstein, G., Stepanek, C., Abe-Ouchi, A., Chan, W.-L., Bragg, F. J., Contoux, C., Dolan, A. M., Hill, D. J., Jost, A., Kamae, Y., Lohmann, G., Lunt, D. J., Rosenbloom, N. A., Sohl, L. E., and Ueda, H.: Mid-pliocene Atlantic Meridional Overturning Circulation not unlike modern, Clim. Past, 9, 1495-1504, doi:10.5194/cp-9-1495-2013, 2013.

Zhao, X., Ladner, B. C., Roessig, K., Wise, Jr, S. W., and Urquhart, E.: Magnetostratigraphy and biostratigraphy of Cenozoic sediments recovered from the Iberia Abyssal Plain, in: Proceedings of the Ocean Drilling Program Scientific Results, 173, edited by: Beslier, M.-O., Whitmarsh, R. B., Wallace, P. J., and Girardeau, J., College Station, Texas, Ocean Drilling Program CD-ROM, 173, doi:10.2973/odp.proc.sr.173.016.2001, 2001. 